\title{
Cell proliferation in the gastric corpus in Helicobacter pylori associated gastritis and after gastric resection
} D A F Lynch, N P Mapstone, A M T Clarke, P Jackson, M F Dixon, P Quirke,
A T R Axon
Little is known of the cell kinetics of the gastric corpus mucosa in $H$ pylori gastritis or after gastric resection. This study aimed to measure mucosal cell proliferation in $H$ pylori gastritis affecting the corpus and to compare this with cell proliferation in the gastric corpus after surgical resection.

\section{Methods}

Patients undergoing routine diagnostic endoscopy were recruited after they had given informed consent. Those taking $\mathrm{H}_{2}$ antagonists, proton pump inhibitors, non-steroidal anti-inflammatory drugs, antibiotics, or bismuth salts were excluded from the study. At endoscopy, using standard forceps, biopsy specimens were taken from the antrum (2) and corpus (3) of the intact stomach. In patients who had undergone gastric resection, biopsy specimens (3) were taken from a point approximately $5-10 \mathrm{~cm}$ from the anastomosis, or $10 \mathrm{~cm}$ from the pylorus in the intact resected stomach, on the greater curve. Two biopsy specimens from each site were placed in $10 \%$ formalin, routinely processed, and stained with haematoxylin and eosin. A modified Giemsa stain was used to detect $H$ pylori. The third biopsy from the corpus or gastric remnant was taken for in vitro bromodeoxyuridine labelling. Only biopsy specimens of the gastric remnant that were of body type mucosa were included in the study. The study was approved by the hospital ethics committee.

BROMODEOXYURIDINE LABELLING

The corpus/remnant biopsy specimen for immunostaining was put immediately into RPMI 1640 (without L-Glutamine) (Gibco) containing bromodeoxyuridine $(5 \mathrm{mg} / 10 \mathrm{ml})$, incubated in a waterbath for 60 minutes at $37^{\circ} \mathrm{C}$, then placed on filter paper and fixed in formalin. Using a three step immunoperoxidase technique, sections were stained with anti-bromodeoxyuridine (DAKOPATT) antibody (1:20 dilution) for 60 minutes. Only sections that were complete and orientated were counted. For the purpose of counting, the gastric mucosa was divided into three zones: zone $1=$ surface and gastric pit; zone $2=$ isthmus; zone $3=$ gland base. The number of cells to be counted was determined by counting consecutive high power fields until the continuous mean varied by less than $5 \%$. Five hundred cells were found to be necessary. The number of positively staining nuclei per 500 
TABLE I Corpus mucosal cell proliferation and Helicobacter pylori gastritis and gastric resection

\begin{tabular}{llll}
\hline & Group & \\
\cline { 2 - 4 } & $\begin{array}{l}\text { Control } \\
(n=13)\end{array}$ & $\begin{array}{l}\text { H pylori+ve } \\
(n=34)\end{array}$ & $\begin{array}{l}\text { Gastric resection } \\
(n=12)\end{array}$ \\
\hline Median age (y) (quartiles) & $44(32 \cdot 3-52 \cdot 3)$ & $\begin{array}{l}41(35-54) \\
14 / 34\end{array}$ & $55(49 \cdot 5-69 \cdot 8)$ \\
Smokers & $7 / 13$ & $1 / 12$ \\
Median LI\% (quartiles): & $0(0-0 \cdot 8)$ & $1 \cdot 5(0 \cdot 4-2 \cdot 7)$ & $1 \cdot 4(0-6 \cdot 9)$ \\
$\quad$ Zone 1 & $9 \cdot 6(5 \cdot 3-12 \cdot 8)$ & $14 \cdot 5(10 \cdot 2-19)$ & $22(14 \cdot 2-33 \cdot 7)$ \\
Zone 2 & $0(0-0 \cdot 4)$ & $0 \cdot 8(0 \cdot 5-1 \cdot 7)$ & $0(0-0 \cdot 6)$ \\
Zone 3 & $3 \cdot 6(2 \cdot 2-4 \cdot 4)$ & $6(4 \cdot 7-7 \cdot 7)$ & $9(5 \cdot 6-12 \cdot 4)$ \\
Total LI\% & & &
\end{tabular}

Subjects with $H$ pylori gastritis of the intact stomach have increased mucosal labelling index (LI\%) (total and zone 2) in the corpus compared with control subjects ( $p=0.002$ and $p=0.004)$. Body-type mucosal cell LI\% (total and zone 2) is higher in the resected stomach group than in subjects with $H$ pylori gastritis $(\mathrm{p}=0.05$ and $\mathrm{p}=0.02)$.

epithelial cell nuclei (or whole section when less than 500 cells were present) was counted in each zone and expressed as a percentage. This value corresponds to the labelling index (LI\%). Only unequivocally stained cells were counted as positive. All sections were counted by one person who was unaware of the endoscopic diagnosis and $H$ pylori status.

\section{STATISTICAL ANALYSIS}

The Mann-Whitney U test was used for analysis of non-parametric data. Spearman rank analysis was used for the correlation studies. A $p$ value of less than 0.05 was regarded as significant.

\section{Results (Tables I and II; Figures 1 and 2)}

Thirteen patients had normal gastric endoscopic appearances with normal antral and corpus histology. Thirty three patients had normal gastric endoscopic appearances with $H$ pylori infection affecting the antrum and corpus. Twelve patients had undergone previous gastric surgery: truncal vagotomy and gastroenterostomy $(n=2)$, partial gastrectomy $(n=2)$, Billroth I $(n=5)$, Billroth II $(n=2)$, and vagotomy and pyloroplasty $(n=1)$. A similar proportion of subjects in each group were smokers. The $\mathrm{LI} \%$ of all three zones varied in the same direction. Most positively staining nuclei for bromodeoxyuridine were situated in zone 2 corresponding to the proliferative compartment of the gastric glands. The LI of the whole gland (total LI\%) and zone 2 are presented (Tables I and II). The total and zone 2 $\mathrm{LI} \%$ of corpus mucosal cells were increased in $H$ pylori gastritis compared with controls

TABLE II Gastric mucosal cell proliferation and Helicobacter pylori status after gastric resection

\begin{tabular}{lcc}
\hline & \multicolumn{3}{l}{ Group } \\
\cline { 2 - 3 } & H pylori+ve $(n=6)$ & H pylori-ve $(n=6)$ \\
\hline Smokers & $4 / 6$ & $3 / 6$ \\
Median LI\% (quartiles): & \\
Zone 1 & $13 \cdot 5(0 \cdot 6-26 \cdot 4)$ & $0 \cdot 3(0-1 \cdot 2)$ \\
Zone 2 & $34 \cdot 4(22 \cdot 5-35 \cdot 2)$ & $15 \cdot 5(13 \cdot 1-16 \cdot 9)$ \\
Zone 3 & $0(0-0 \cdot 3)$ & $0 \cdot 3(0-1 \cdot 5)$ \\
Total LI\% & $16 \cdot 3(8 \cdot 2-20 \cdot 3)$ & $5 \cdot 7(4 \cdot 6-6 \cdot 5)$ \\
\hline
\end{tabular}

Subanalysis of patients with gastric resection indicates that $H$ pylori positive subjects have higher corpus mucosal labelling indices $(\mathrm{LI} \%)$ than patients who are $H$ pylori negative $(\mathrm{p}=0.03$ and $\mathrm{p}=0.004)$.

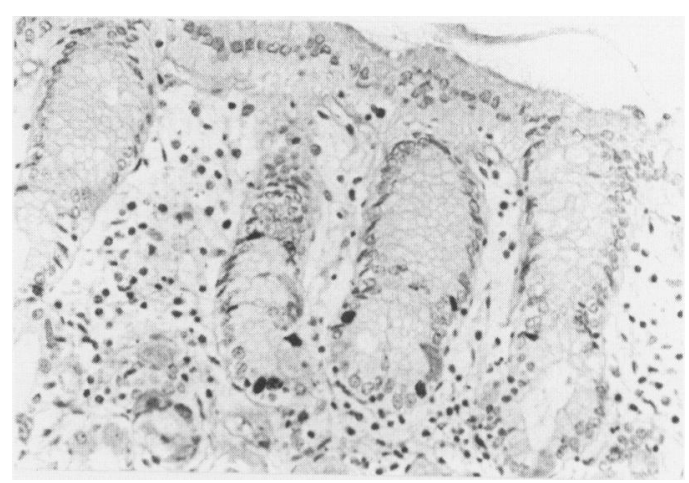

Figure 1: Bromodeoxyuridine labelling in normal gastric corpus mucosa. (Original magnification $\times 37$.)

$(p=0.002$ and $p=0.004)$. The corpus mucosal cell $\mathrm{LI} \%$ (total and zone 2) was increased in gastric resection patients compared with those with $H$ pylori gastritis $(\mathrm{p}=0.05$ and $\mathrm{p}=0.02)$. Subanalysis of patients who had undergone gastric surgery showed that those positive for $H$ pylori had increased mucosal cell total and zone $2 \mathrm{LI} \%$ compared with those negative for the organism $(p=0.03$ and $p=0.004)$. The distribution of the different forms of gastric surgery was similar in the positive (truncal vagotomy and gastroenterostomy $(n=1)$, polya partial gastrectomy $(n=1)$, Billroth I $(n=2)$, Billroth II $(n=1))$, vagotomy and pyloroplasty $(n=1)$ and negative (truncal vagotomy and pyloroplasty $(n=1)$, polya partial gastrectomy $(n=1)$, Billroth I $(n=3)$, Billroth II $(n=1)$, groups. There was no correlation between patient age and corpus mucosal $\mathrm{LI} \%$ in controls $(R=-0.25 ; p=0.41)$, subjects with $H$ pylori gastritis $(\mathrm{R}=-0.03 ; \mathrm{p}=0.87)$, or patients with gastric resection $(R=-0.07$; $\mathrm{p}=0 \cdot 8)$.

\section{Discussion}

Epidemiological evidence supports a role for $H$ pylori in gastric carcinogenesis. ${ }^{7-10}$ We have shown that epithelial cell proliferation in the corpus is increased in $H$ pylori gastritis. This is consistent with our previous finding of increased cell proliferation in the antrum in this condition. ${ }^{11} \mathrm{H}$ pylori damages the gastric mucosa and this leads to a compensatory increase in mucosal proliferation which may

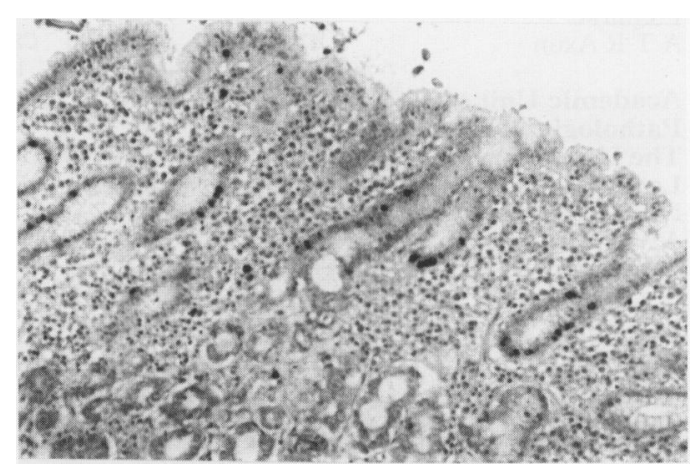

Figure 2: Bromodeoxyuridine labelling in $\mathrm{H}$ pylori gastritis affecting the corpus where zone 2 and the total labelling index are increased. (Original magnification $\times 37$.) 
expose vulnerable cells to luminal mutagens. Eradication of the organism leads to a reduction in antral mucosal cell proliferation levels to normal. ${ }^{11}$

Bile reflux induces a distinctive histopathological picture which has been termed 'reflux' or 'chemical' gastritis. ${ }^{12}$ Bile, invariably present after operations that by-pass or destroy the pylorus, is recognised to have cocarcinogenic properties. ${ }^{45}$ Furthermore, colonisation of the hypochlorhydric resected stomach by bacteria, more characteristic of the faecal flora, leads to the production of nitrosating bacteria which may accelerate the production of carcinogenic N-nitrosocompounds. ${ }^{13}$ Thus, an increase in gastric mucosal cell permeability caused by bile reflux could expose the epithelial cell nuclei to mutagenic agents present in the lumen of the resected stomach. We have shown that body-type mucosa in the resected stomach has even higher levels of cell proliferation than those found in $H$ pylori gastritis in unoperated individuals.

The finding that $H$ pylori infection of the resected stomach has a synergistic effect on gastric mucosal cell proliferation is of particular interest. Though bile reflux may inhibit colonisation of the gastric mucosa by $H$ pylori the two often coexist. ${ }^{14}$ The combination of $H$ pylori and bile reflux seems to cause greater epithelial damage with an increased proliferative response. The presence of these agents together in the intact stomach has a synergistic effect on the development of intestinal metaplasia $^{14}$ and is compatible with our findings. Furthermore, surgical diversion of bile reduces epithelial cell proliferation in the gastric remnant. ${ }^{15}$

We have shown that there is no correlation between patient age and mucosal cell proliferation in normal or diseased mucosa. Although the numbers involved are small, we believe that the difference in age distribution between subjects with $H$ pylori associated gastritis and patients with a resected stomach would not account for the difference in mucosal cell proliferation. Other factors such as the underlying morphology of the mucosa, ${ }^{16}$ inflammatory mediators, ${ }^{17}$ or growth regulatory peptides ${ }^{18}$ are likely to be important.

In conclusion, corpus mucosal cell proliferation is increased in $H$ pylori gastritis. Body-type mucosa in the resected stomach has higher proliferation levels than $H$ pylori gastritis affecting the intact stomach. $H$ pylori positive patients who have undergone resection exhibit a higher $\mathrm{LI} \%$ than their uninfected counterparts. These data may be explained by synergism between $H$ pylori infection and whatever causes increased cell proliferation in the gastric corpus after gastric surgery. The most likely culprit is bile reflux. These two factors, $H$ pylori and bile, may be the major players in the development of cancer of the gastric remnant.

1 Offerhaus GJA, Tersmette AC, Huibregste $\mathrm{K}$, et al. Mortality caused by stomach cancer after remote partial gastrectomy for benign conditions; 40 years of follow-up of an Amsterdam cohort of 2633 postgastrectomy patients. Gut 1988; 29: 1588-90.

2 Caygill CPJ, Hill MJ, Kirkham JS, Northfield TC. Mortality from gastric cancer following gastric surgery for peptic ulcer. Lancet 1986; ii: 502-5.

3 Clark CG, Ward MWN, McDonald AM, Tovey FI. The incidence of gastric stump cancer. World f Surg 1983; 7: 236-40.

4 Sano C, Kumashiro R, Saito T, Inokuchi K. Promoting effect of partial gastrectomy on carcinogenesis in the remnant stomach of rats after oral administration of N-methyl-N-nitro-N-nitrosoguanidine. Oncology 1984; 41: 124-8.

5 Weiman TJ, Max MH, Vogles CR, Burrows GH. Diversion of duodenal contents. Its effect on the production of experimental gastric cancer. Arch Surg 1980; 115: 959-61

6 Medline A, Farber E. The multi-step theory of neoplasia. In: Anthony PP, Sweeney RMN, eds. Recent advances in histopathology. No 11. Edinburgh: Churchill Livingstone, 1981: 19-34.

7 Nomura A, Stemmermann GN, Chyou P, Kato I, PerezPerez GI, Blaser MJ. Infection and gastric carcinoma among Japanese Americans in Hawaii. $N$ Engl $f$ Med 1991; 325: 16, 1132-6.

8 Forman D, Newell DG, Fullerton F, Yarnell JWG, Stacey AR, Wald N, Sitas F. Association between infection with Helicobacter pylori and risk of gastric cancer: evidence from a prospective investigation. $B M \mathcal{F}$ 1991; 302: 1302-5.

9 Parsonnet J, Friedman GD, Vandersteen DP, Chang Y, Vogelman $\mathrm{JH}$, Orentreich $\mathrm{N}$, et al. Helicobacter pylor 1991; 325: 1172-31.

10 The Eurogast Study Group. An international association between Helicobacter pylori infection and gastric cancer between Helicobacter pylor
Lancet 1993; 341: 1359-62.

11 Lynch DAF, Mapstone NP, Clarke AMT, Jackson P, Dixon MF, Quirke $\mathrm{P}$, et al. Cell proliferation in Helicobacter pylori associated gastritis and the effect of eradication therapy. Gut 1993; 34 (suppl 1): W12.

12 Dixon MF, O'Connor HJ, Axon ATR, King RFG, Johnston D. Reflux gastritis: distinct histopathological entity? $f$ Clin Pathol 1986; 39: 524-30.

13 Ruddell WSJ, Axon ATR, Findley JM, Bartholomew BA, Hill MJ. The effect of cimetidine on gastric bacterial flora. Lancet 1980; i: 672-4.

14 Sobala GM, O'Connor HJ, Dewar EP, King RFG, Axon ATR, Dixon MF. Histological consequences of bile reflux on the gastric mucosa, with special reference to intestinal on the gastric mucosa, with special reference
metaplasia. F Clin Pathol 1993; 46: 235-40.

15 Bechi P, Balzi M, Becciolini A, Amorosi A, Scubla E, Giache V, et al. Gastric cell proliferation kinetics and bile reflux after partial gastrectomy. Am $\mathcal{F}$ Gastroenterol 1991 86 (10): 1424-32.

16 Lynch DAF, Mapstone NP, Lewis F, Dixon MF, Quirke P, Axon ATR. Correlation between cell proliferation in $\mathrm{H}$ pylori associated gastritis and histological scoring using the Sidney System. Gut 1993; 34 (suppl 4): F197.

17 Emery P, Salmon M. Systemic mediators of inflammation. Brf Hosp Med 1991; 45: 164-8.

18 Jankowski J, McMenemin R, Hopwood D. Penston J, Wormsley KG. Growth regulatory peptides in gastric mucosa. Clin Sci 1991; 81: 663-8. 